\title{
Prevention of beta cell "karoshi": a new paradigm for prevention and management of type 2 diabetes
}

\author{
Author: \\ Yoshifumi Saisho, $\mathrm{MD}, \mathrm{PhD}$ \\ Tokyo, Japan \\ Corresponding author: \\ Yoshifumi Saisho, MD, PhD \\ Department of Internal Medicine \\ Keio University School of Medicine \\ 35 Shinanomachi, Shinjuku-ku, Tokyo 160-8582, Japan \\ TEL: +81-3-3353-1211 (x62383) \\ FAX: +81-3-3359-2745 \\ E-mail: ysaisho@keio.jp
}

Department of Internal Medicine, Keio University School of Medicine,

Word count: Main text 1,364 words, 8 figures

Key words: type 2 diabetes, prevention, beta cell, lifestyle modification, empowerment 
"It is better to try to avoid problems in the first place, rather than trying to fix them once they arise."

Benjamin Franklin

Diabetes is a pandemic disease. According to the International Diabetes Federation, the number of people with diabetes throughout the world is projected to reach 415 million in 2015 and to rise to 642 million in 2040 (1). Every 6 seconds, a person dies from diabetes (5.0 million deaths in 2015). The cost of diabetes treatment is estimated to be $12 \%$ of global health expenditure (673 billion dollars in 2015). Diabetes is not only a medical problem but also one of the biggest socioeconomic problems in the world.

Most patients with diabetes are classified as having type 2 diabetes (T2DM). T2DM is characterized by insulin resistance and beta cell dysfunction (2). Since people with T2DM are typically characterized by obesity, insulin resistance and hyperinsulinemia, T2DM is often assumed to contrast to type 1 diabetes (T1DM) in which beta cells are destroyed by autoimmune attack, and the significance of beta cell dysfunction in $\mathrm{T} 2 \mathrm{DM}$ is often underestimated or even ignored.

However, recent studies have shown that beta cell mass is decreased in both T1DM and T2DM (Figure 1) (3, 4), suggesting the presence of beta cell deficit in T2DM. The deficit of beta cells in patients with T2DM is observed across 
ethnic groups (5-9), suggesting that a

deficit of beta cells is a universal pathological feature of T2DM. Thus, the concept of diabetes is now changing to a new one in which deficit of beta cells is a common pathological feature of both T1DM and T2DM (10). The distinctions between the two are the cause (autoimmune vs. insulin resistance) and the extent of deficit (almost complete vs. partial) (Figure 2).

Recent studies have also shown that diabetes is a progressive disease. Progressive loss of beta cell function as well as beta cell mass has been reported, while insulin resistance remains unchanged with the disease duration $(6,10,11)$, suggesting that the progressive nature of $\mathrm{T} 2 \mathrm{DM}$ is mainly due to progressive loss of functional beta cell mass. The UK Prospective Diabetes Study (UKPDS) showed that beta cell function assessed by homeostasis model assessment (HOMA) was decreased by $\sim 50 \%$ at the time of diagnosis of T2DM, and progressively decreased by $\sim 5 \%$ a year (12). This also suggests that loss of functional beta cell mass begins $\sim 10$ years before the onset of T2DM. A reduction in beta cell mass in individuals with prediabetes has also been reported (Figure 1) (3, 13). These findings highlight that beta cell loss has already started far before the onset of hyperglycemia (Figure 3). This new concept indicates that T2DM does not develop in the absence of beta cell dysfunction. That is, although 
T2DM is characterized by insulin resistance and beta cell dysfunction, beta cell deficit is necessary for the development of T2DM (Figure 4). In obese non-diabetic individuals, insulin secretion increases two to three fold to compensate insulin resistance (14).

However, it has been shown that, unlike in rodents, compensatory beta cell mass expansion in response to insulin resistance is very limited in humans (Figure 5) $(8,9,15,16)$, suggesting that an increase in insulin secretion per beta cell rather than an increase in the number of beta cells is the major compensatory mechanism against obesity and insulin resistance in humans. Based on these findings, we here propose the beta cell workload hypothesis (Figure 6) (10). That is, in the face of insulin resistance, beta cells work harder to secrete more insulin to maintain normoglycemia. If excess workload on beta cells continues, stress-induced beta cell death (apoptosis) may eventually occur and beta cell mass is reduced. Plausible mechanisms by which beta cell death is induced have been proposed, such as oxidative stress (17), endoplasmic reticulum (ER) stress (18, 19), mitochondrial dysfunction (20), amyloid toxicity $(21,22)$, inflammatory cytokines (23) and autophagy dysfunction (24). A recent rodent study has also suggested beta cell dedifferentiation as a mechanism of beta cell loss in diabetes (25). Once beta cell mass is reduced, each residual beta cell will be exposed to an even greater workload, which results in a 
vicious cycle fostering further beta cell

loss. When functional beta cell mass eventually fails to compensate insulin resistance, hyperglycemia develops. Hyperglycemia further augments beta cell workload and beta cell toxicity, so-called gluco(lipo)toxicity (26), which leads to further loss of beta cells, reflecting the progressive nature of this disease (Figure 7). Since, unfortunately, the current therapy for T2DM does not reverse or cure the disease, this concept emphasizes the importance of beta cell preservation for the prevention of T2DM.

This change in the concept of diabetes is important because current therapy for diabetes cannot reverse or cure the deficit of beta cells. From knowledge obtained from a number of clinical studies in patients with T2DM and prediabetes, we now appreciate that reduction of beta cell workload is a key strategy to preserve residual beta cell function $(10,27)$. Proposed treatment strategies for type 2 diabetes aiming at reducing beta cell workload are shown in Figure 8.

Elimination of insulin resistance by metabolic surgery is expected to be a potential therapy leading to a cure for diabetes (28). However, even if drastic weight loss can be achieved after surgery, remission of diabetes occurs only in a small proportion of subjects (29). This suggests that even if insulin resistance can be eliminated, beta cell deficit remains in patients with T2DM.

So what should we learn from these facts? We really need to focus on 
protection of beta cells even prior to the

development of diabetes, emphasizing

education not only of people with diabetes

but also those without diabetes. We need

to share this new and important concept of

diabetes with the general population all

over the world and recognize that most of

the functional beta cell mass is already

lost when hyperglycemia develops. The

development of hyperglycemia in the

diabetic range may indicate that the

person has already crossed the point of

no-return in terms of beta cell reserve.

A key to the prevention of T2DM is

lifestyle modification, including a healthy

diet and increased physical activity (30,

31). Lifestyle modification is indeed the

most fundamental and effective therapy

for patients with T2DM as well $(32,33)$, presumably reducing beta cell workload through the improvement of obesity and insulin resistance. Considering the fact that one in eleven adults throughout the world are assumed to have diabetes (1), lifestyle modification for patients with T2DM should apply to most adults (and children) all over the world.

Lifestyle modification requires self-management. It is therefore important for not only patients with T2DM but also the general population to correctly understand diabetes in order to empower them. Our mindset should change from saying that a bad lifestyle is not good for your health to saying that your beta cells should be protected through a healthy lifestyle, to prevent the development of T2DM. There is a limited source of beta 
cells in the human body, which weigh

only $\sim 1$ g. Having a healthy lifestyle is a

consequence of individual choice. To

maintain individuals' motivation to

continue making healthy choices in their

daily life, it is important to correctly

understand the nature of the disease.

"Karoshi" is a Japanese term which can be

translated literally as "death from

overwork" (34) causing occupational

sudden mortality. Here we propose that

we should call beta cell death due to

excess workload under insulin resistance,

beta cell "karoshi", which may be more

easily understandable for the general

population of our society. The concept of

beta cell "karoshi" may help people to

imagine protecting their own beta cells

from overwork that leads to beta cell death or "karoshi", and could empower and motivate them to make better choices.

So, diabetes is now a serious social

problem throughout the world. Patients with T2DM provide an important message to our society. Lifestyle modification is the most fundamental treatment for T2DM as well as its prevention. A huge body of work has revealed that protection of beta cells is undoubtedly a key message in order to achieve this goal. We should learn from patients with T2DM and fight with them to prevent this pandemic disease. The concept of beta cell "karoshi" not only empowers people to adhere to a healthy lifestyle, but also may foster a policy change to improve our "toxic" environment which increases obesity and stresses our beta cells. 
Medical Research Archives, Vol. 4, Issue 6, October 2016

Prevention of beta cell "karoshi"

\section{Acknowledgements}

We thank Dr. Wendy Gray,

self-employed, for editing the manuscript.

\section{Conflict of interest}

The author has no conflict of

interest regarding this manuscript. 


\section{References}

1. International Diabetes Federation. IDF Diabetes Atlas, 7th edn. 2016 [Available from: http://www.idf.org/diabetesatlas.

2. Saisho Y. Obesity, type 2 diabetes and beta cell failure: An Asian perspective. J Mol Genet Med. 2014;S1:008.

3. Butler AE, Janson J, Bonner-Weir S, Ritzel R, Rizza RA, Butler PC. Beta-cell deficit and increased beta-cell apoptosis in humans with type 2 diabetes. Diabetes. 2003;52(1):102-10.

4. Meier JJ, Bhushan A, Butler AE, Rizza RA, Butler PC. Sustained beta cell apoptosis in patients with long-standing type 1 diabetes: indirect evidence for islet regeneration? Diabetologia. 2005;48(11):2221-8.

5. Yoon KH, Ko SH, Cho JH, Lee JM, Ahn YB, Song $\mathrm{KH}$, et al. Selective beta-cell loss and alpha-cell expansion in patients with type 2 diabetes mellitus in Korea. J Clin Endocrinol Metab. 2003;88(5):2300-8.

6. Rahier J, Guiot Y, Goebbels RM, Sempoux C, Henquin JC. Pancreatic beta-cell mass in European subjects with type 2 diabetes. Diabetes Obes Metab. 2008;10 Suppl $4: 32-42$.

7. Sakuraba H, Mizukami H, Yagihashi N, Wada R, Hanyu C, Yagihashi S. Reduced beta-cell mass and expression of oxidative stress-related DNA damage in the islet of Japanese Type II diabetic patients. Diabetologia. 2002;45(1):85-96.

8. Sato S, Saisho Y, Inaishi J, Kou K, Murakami R, Yamada T, et al. Effects of Glucocorticoid
Treatment on beta- and alpha-Cell Mass in Japanese Adults With and Without Diabetes. Diabetes. 2015;64(8):2915-27.

9. Inaishi J, Saisho Y, Sato S, Kou K, Murakami R, Watanabe Y, et al. Effects of Obesity and Diabetes on alpha- and beta-Cell Mass in Surgically Resected Human Pancreas. J Clin Endocrinol Metab. 2016;101(7):2874-82.

10. Saisho Y. Beta cell dysfunction: Its critical role in prevention and management of type 2 diabetes. World J Diabetes. 2015;6(1):109-24.

11. Kendall DM, Cuddihy RM, Bergenstal RM. Clinical application of incretin-based therapy: therapeutic potential, patient selection and clinical use. Am J Med. 2009;122(6 Suppl):S37-50.

12. U.K. Prospective Diabetes Study Group. U.K. prospective diabetes study 16 . Overview of 6 years' therapy of type II diabetes: a progressive disease. Diabetes. 1995;44(11):1249-58.

13. Meier JJ, Breuer TG, Bonadonna RC, Tannapfel A, Uhl W, Schmidt WE, et al. Pancreatic diabetes manifests when beta cell area declines by approximately $65 \%$ in humans. Diabetologia. 2012;55(5):1346-54.

14. Polonsky KS, Given BD, Van Cauter E. Twenty-four-hour profiles and pulsatile patterns of insulin secretion in normal and obese subjects. J Clin Invest. $1988 ; 81(2): 442-8$.

15. Saisho Y, Butler AE, Manesso E, Elashoff D, Rizza RA, Butler PC. b-Cell Mass and 
Turnover in Humans: Effects of obesity and aging. Diabetes Care. 2013;36(1):111-7.

16. Kou K, Saisho Y, Satoh S, Yamada T, Itoh H. Change in beta-cell mass in Japanese nondiabetic obese individuals. $\mathrm{J}$ Clin Endocrinol Metab. 2013;98(9):3724-30.

17. Robertson RP. Antioxidant drugs for treating beta-cell oxidative stress in type 2 diabetes: glucose-centric versus insulin-centric therapy. Discov Med. 2010;9(45):132-7.

18. Scheuner D, Kaufman RJ. The unfolded protein response: a pathway that links insulin demand with beta-cell failure and diabetes. Endocr Rev. 2008;29(3):317-33.

19. Eizirik DL, Cardozo AK, Cnop M. The role for endoplasmic reticulum stress in diabetes mellitus. Endocr Rev. 2008;29(1):42-61.

20. Supale S, Li N, Brun T, Maechler P. Mitochondrial dysfunction in pancreatic beta cells. Trends in endocrinology and metabolism: TEM. 2012;23(9):477-87.

21. Haataja L, Gurlo T, Huang CJ, Butler PC. Islet amyloid in type 2 diabetes, and the toxic oligomer hypothesis. Endocr Rev. 2008;29(3):303-16.

22. Hull RL, Westermark GT, Westermark P, Kahn SE. Islet amyloid: a critical entity in the pathogenesis of type 2 diabetes. J Clin Endocrinol Metab. 2004;89(8):3629-43.

23. Dinarello CA, Donath MY, Mandrup-Poulsen T. Role of IL-1beta in type 2 diabetes. Current opinion in endocrinology, diabetes, and obesity. 2010;17(4):314-21.

24. Masini M, Bugliani M, Lupi R, del Guerra S,
Boggi U, Filipponi F, et al. Autophagy in human type 2 diabetes pancreatic beta cells. Diabetologia. 2009;52(6):1083-6.

25. Talchai C, Xuan S, Lin HV, Sussel L, Accili D. Pancreatic beta cell dedifferentiation as a mechanism of diabetic beta cell failure. Cell. 2012;150(6):1223-34.

26. Poitout V, Robertson RP. Glucolipotoxicity: fuel excess and beta-cell dysfunction. Endocr Rev. 2008;29(3):351-66.

27. DeFronzo RA, Abdul-Ghani MA. Preservation of beta-cell function: the key to diabetes prevention. J Clin Endocrinol Metab. 2011;96(8):2354-66.

28. Cefalu WT, Rubino F, Cummings DE. Metabolic Surgery for Type 2 Diabetes: Changing the Landscape of Diabetes Care. Diabetes Care. 2016;39(6):857-60.

29. Mingrone G, Panunzi S, De Gaetano A, Guidone C, Iaconelli A, Nanni G, et al. Bariatric-metabolic surgery versus conventional medical treatment in obese patients with type 2 diabetes: 5 year follow-up of an open-label, single-centre, randomised controlled trial. Lancet. 2015;386(9997):964-73.

30. Li G, Zhang P, Wang J, An Y, Gong Q, Gregg EW, et al. Cardiovascular mortality, all-cause mortality, and diabetes incidence after lifestyle intervention for people with impaired glucose tolerance in the Da Qing Diabetes Prevention Study: a 23-year follow-up study. Lancet Diabetes Endocrinol. 2014.

31. Knowler WC, Fowler SE, Hamman RF, 
Christophi CA, Hoffman HJ, Brenneman AT, et al. 10-year follow-up of diabetes incidence and weight loss in the Diabetes Prevention Program Outcomes Study. Lancet. 2009;374(9702):1677-86.

32. Inzucchi SE, Bergenstal RM, Buse JB, Diamant M, Ferrannini E, Nauck M, et al. Management of Hyperglycemia in Type 2 Diabetes, 2015: A Patient-Centered Approach: Update to a Position Statement of the American Diabetes Association and the European Association for the Study of Diabetes. Diabetes Care. 2015;38(1):140-9.

33. International Diabetes Federation Guideline Development Group. Global Guideline for
Type 2 Diabetes. Diabetes research and clinical practice. 2014;104(1):1-52.

34. Wikipedia. [Available from: https://en.wikipedia.org/wiki/Kar\%C5\%8Dsh i.

35. Tschen SI, Dhawan S, Gurlo T, Bhushan A. Age-dependent decline in beta-cell proliferation restricts the capacity of beta-cell regeneration in mice. Diabetes. 2009;58(6):1312-20.

36. Saisho Y. Importance of Beta Cell Function for the Treatment of Type 2 Diabetes. Journal of Clinical Medicine. 2014;3(3):923-43. 


\section{Figures}

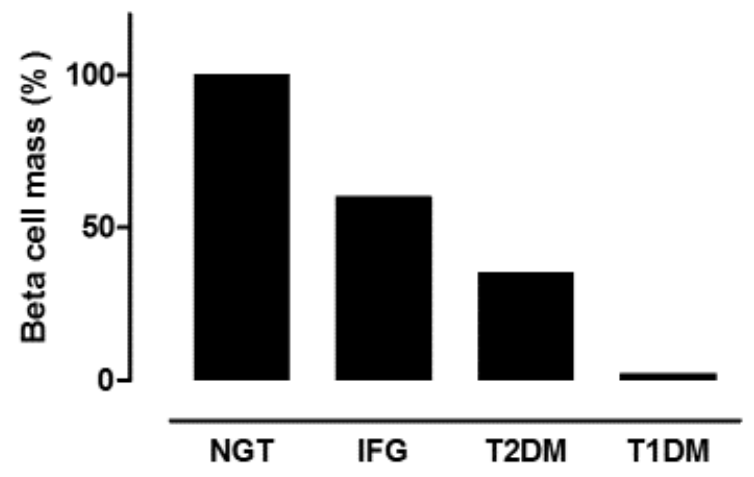

Figure 1. Beta cell mass in patients with normal glucose tolerance (NGT), impaired fasting glycemia (IFG), type 2 diabetes (T2DM) and long-standing type 1 diabetes (T1DM). Adapted and modified from the study by Butler et al. (3) and (4). 


\begin{tabular}{|c|c|c|}
\hline \multicolumn{3}{|l|}{ Past } \\
\hline & Type 1 diabetes & Type 2 diabetes \\
\hline & $\begin{array}{c}\text { Beta cell destruction } \\
\text { Beta cell mass } \downarrow \downarrow \\
\text { Insulin secretion } \downarrow\end{array}$ & $\begin{array}{l}\text { Obesity } \\
\text { Insulin resistance } \\
\text { Hyperinsulinemia }\end{array}$ \\
\hline \multicolumn{3}{|l|}{ Present } \\
\hline & Type 1 diabetes & Type 2 diabetes \\
\hline & $\begin{array}{c}\text { Beta cell destruction } \\
\text { Beta cell mass } \downarrow \downarrow \\
\text { Insulin secretion } \downarrow\end{array}$ & $\begin{array}{l}\text { Beta cell loss } \\
\text { Beta cell mass } \downarrow \\
\text { Insulin secretion } \downarrow\end{array}$ \\
\hline Causes & Autoimmune & $\begin{array}{l}\text { Insulin resistance } \\
\text { Beta cell overwork }\end{array}$ \\
\hline
\end{tabular}

Figure 2. Changing concepts of pathogenesis of type 1 and type 2 diabetes in the past and present. 
Medical Research Archives, Vol. 4, Issue 6, October 2016

Prevention of beta cell "karoshi"

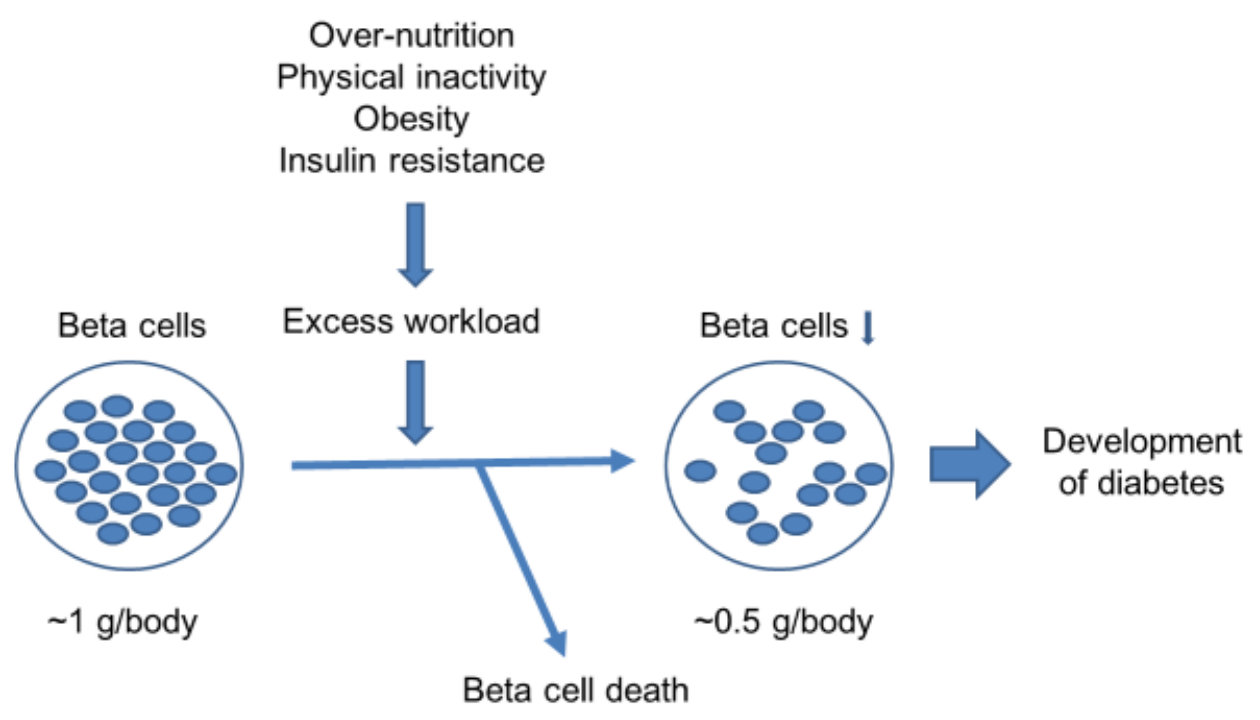

Figure 3. Conceptual schema of beta cell change during development of type 2 diabetes. 


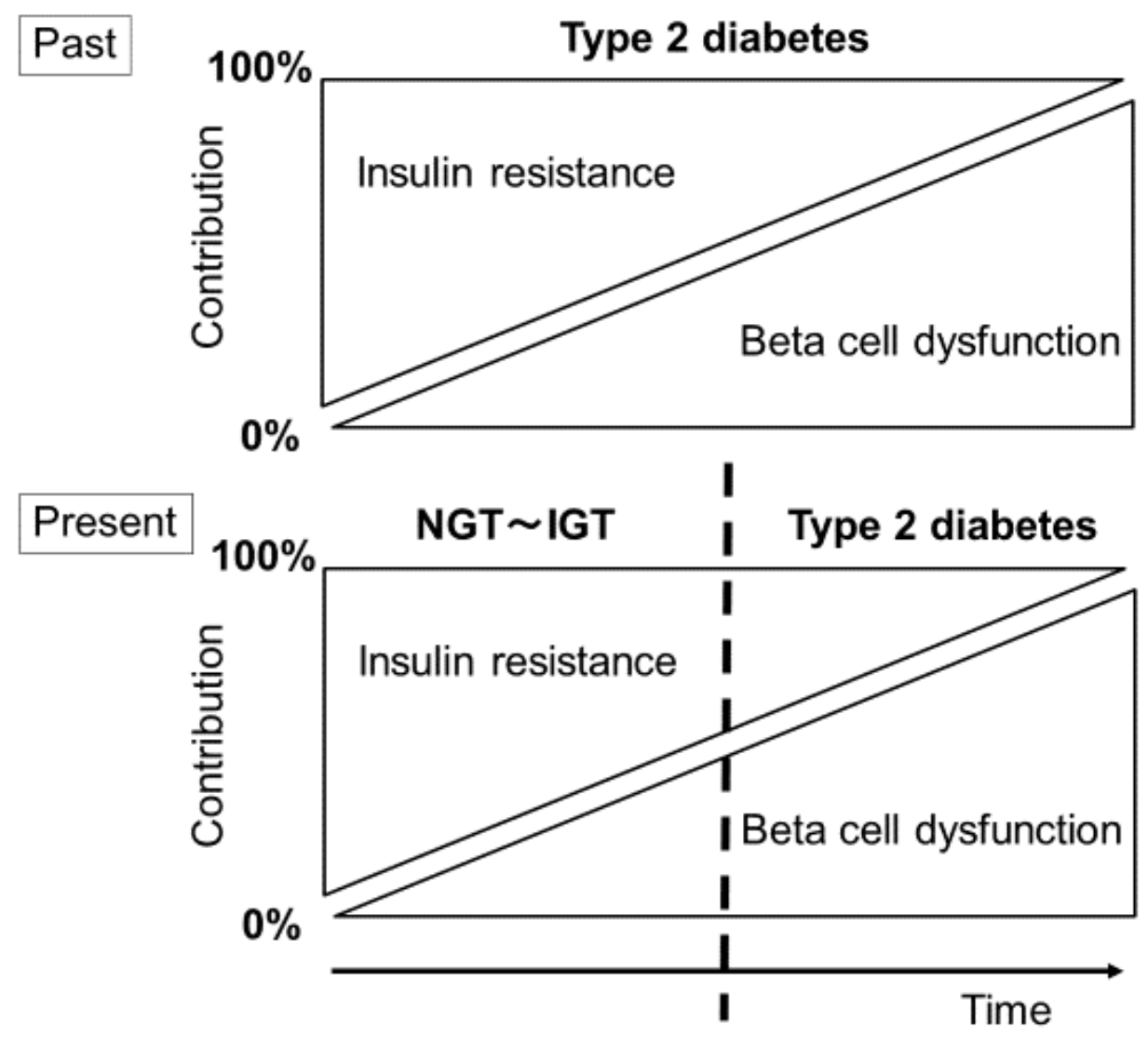

Figure 4. New concept of relative contributions of insulin resistance and beta cell dysfunction in type 2 diabetes. Type 2 diabetes never develops without beta cell dysfunction. This new concept indicates the need for beta cell protection before the onset of T2DM. NGT; normal glucose tolerance. IGT; impaired glucose tolerance. 


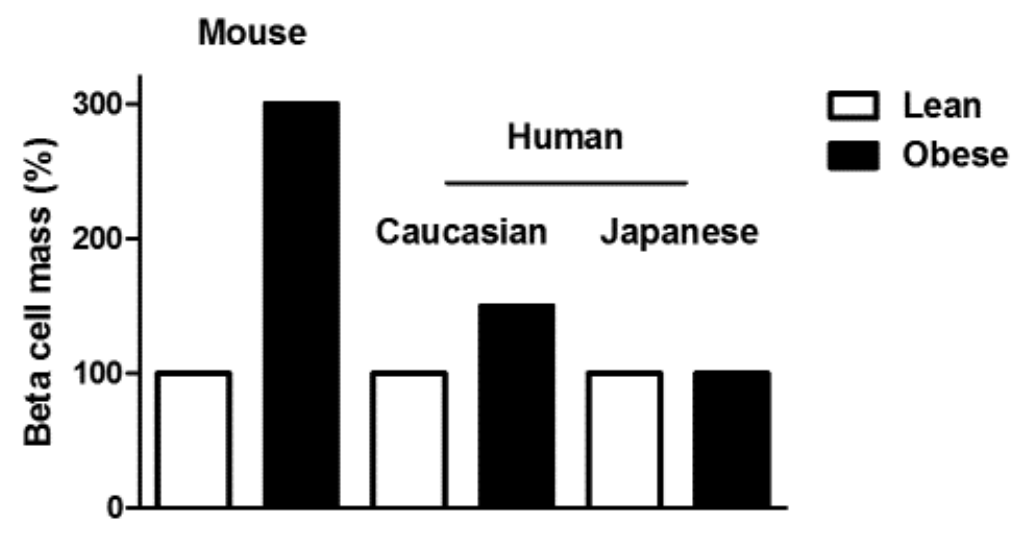

Figure 5. Change in beta cell mass with obesity. In mice, beta cell mass increases 3 -fold with obesity. In humans, a 50\% increase in beta cell mass has been reported in Caucasians, while no increase was reported in Japanese. Adopted and modified from ref. $(15,16,35)$. 


\author{
Obesity \\ Insulin resistance
}

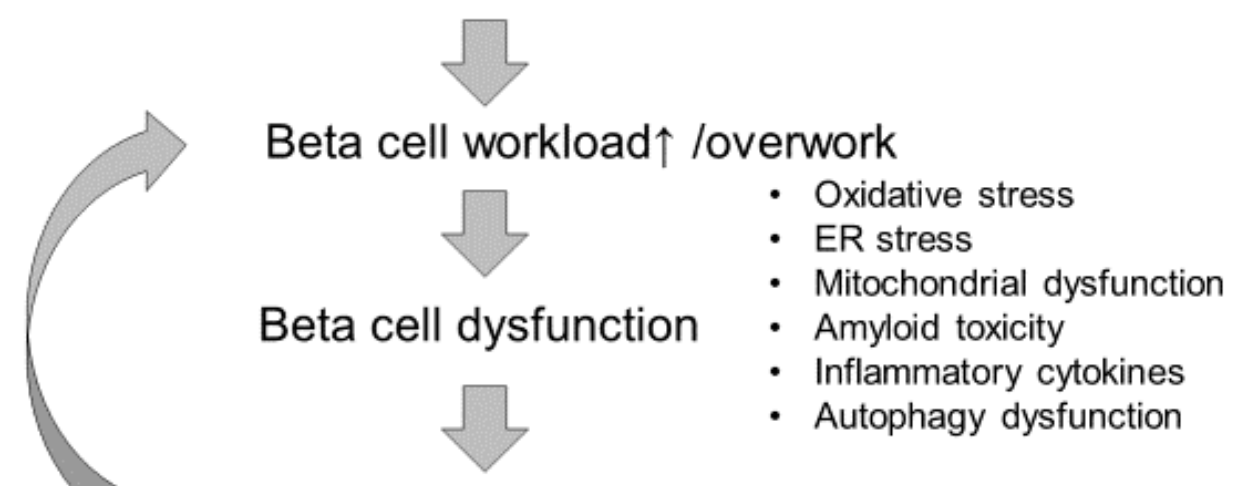

Functional beta cell mass $\downarrow$

B

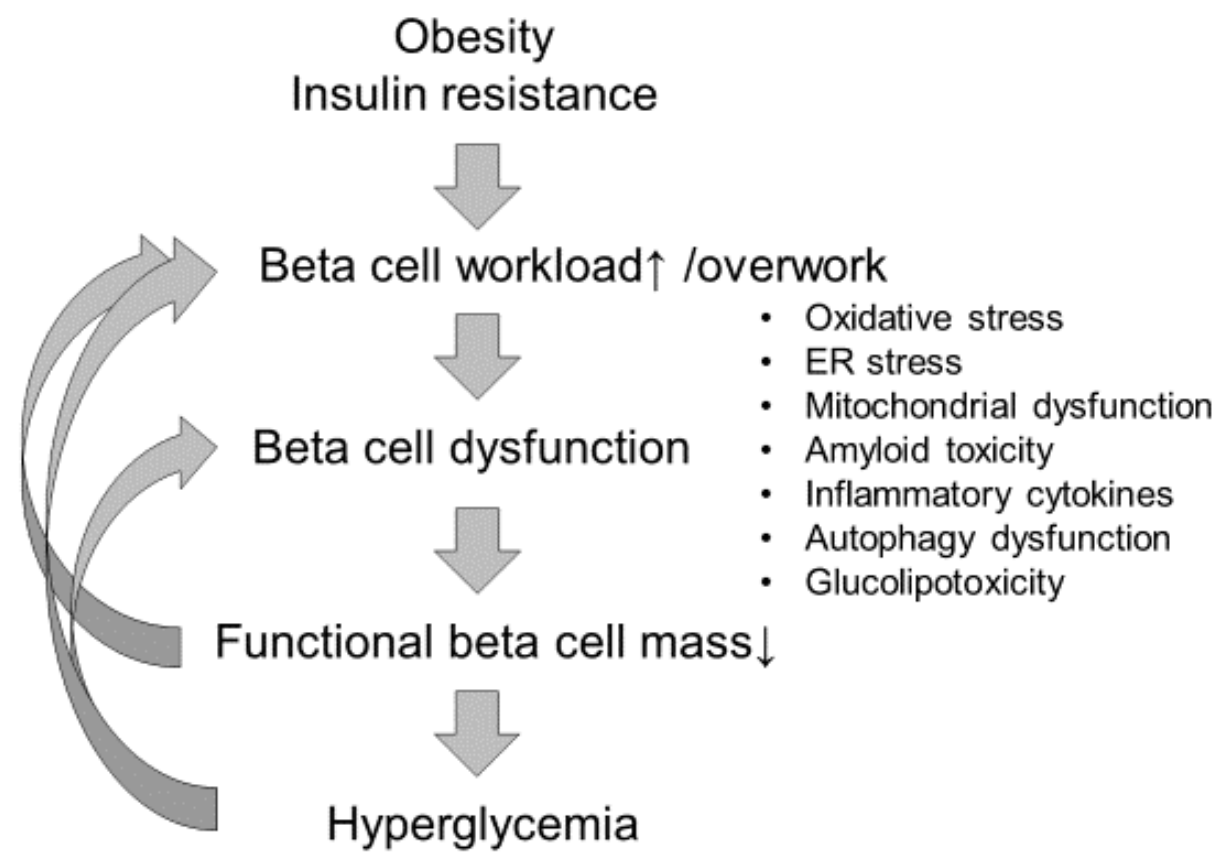

Figure 6. Proposed mechanisms of beta cell death before (A) and after (B) the development of type 2 diabetes (hyperglycemia). Increased beta cell workload induces beta cell loss through various mechanisms and once hyperglycemia develops, gluco(lipo)toxicity causes further beta cell loss. 


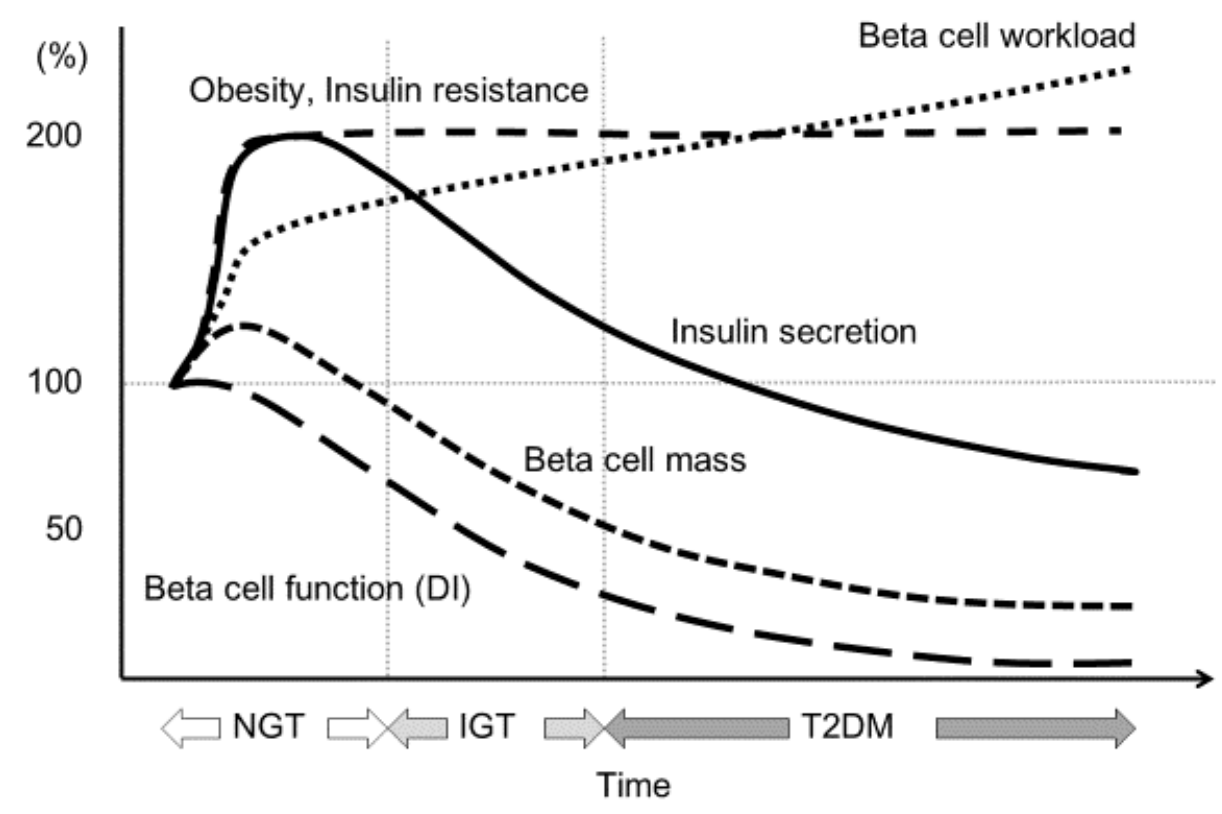

Figure 7. Chronological change in functional beta cell mass in relation to beta cell workload during the development of T2DM. Adopted from ref(10). Recent studies have suggested that functional beta cell mass is already reduced at the onset of T2DM. Excess workload on beta cells induced by insulin resistance continues, stress-induced beta cell death, "karoshi", may eventually occur, and beta cell mass is reduced even before the onset of diabetes. Once beta cell mass is reduced, the workload on residual beta cell is further exaggerated, reflecting the progressive nature of the disease. 


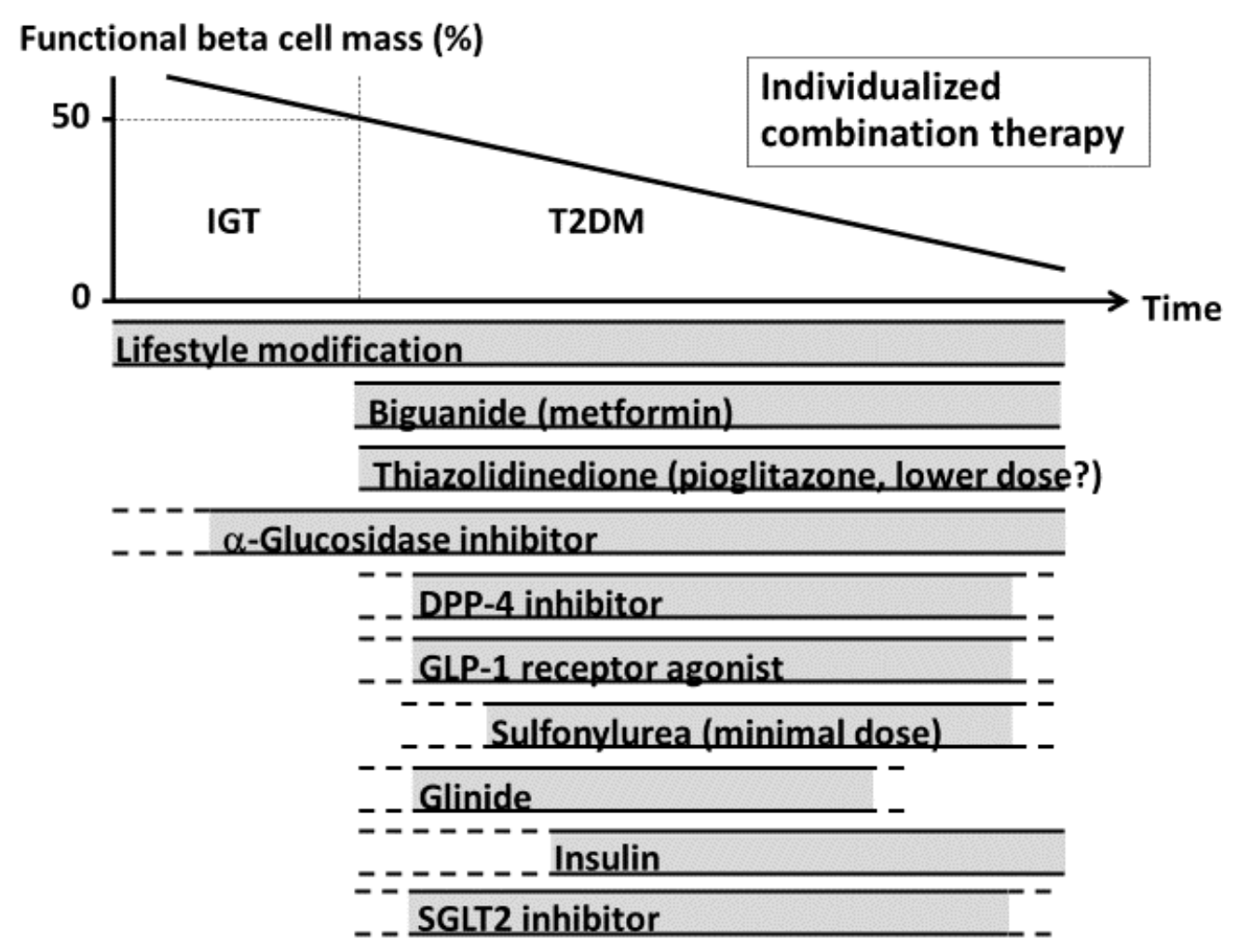

Figure 8. Proposed concept of treatment strategy for type 2 diabetes (T2DM) in relation to functional beta cell mass. Adopted and modified from $\operatorname{ref}(2,36)$. An $\alpha$-glucosidase inhibitor is partly approved for use in patients with impaired glucose tolerance (IGT) in Japan. Medications not approved in Japan are not included in the figure. Since currently no single therapy or agent can cure and even manage T2DM, an effective combination of current medications in addition to lifestyle modification aiming at reduction in beta cell workload is important to preserve or recover beta cell function. SGLT2 inhibitors, the most recently marketed anti-diabetic drug class, show a glucose-lowering effect through an increase in urinary glucose excretion. This effect is insulin-independent, and thus SGLT2 inhibitors reduce beta cell workload. 